\title{
Impact of Tourism Destination Strategy on Its Competitiveness
}

\author{
Dunja Demirović \\ University of Novi Sad, Faculty of Sciences, Serbia \\ Radovan Pejanović \\ University of Novi Sad, Faculty of Agriculture, Serbia \\ Otilija Sedlak \\ University of Novi Sad, Faculty of Economics, Serbia \\ Kristina Košić \\ University of Novi Sad, Faculty of Sciences, Serbia
}

\begin{abstract}
The aim of this paper is to explore how destination strategy - marketing, employees, policy of planning and destination development, management of service quality and management of environmental protection - affects competitiveness of rural tourism destinations in Vojvodina (Serbia) and Hungary. Tourism experts in Vojvodina (136) and Hungary (138) were asked to evaluate the current condition of all 24 attributes which affect the competitiveness of rural tourism destinations. Likert scale of five marks was used in order to determine the effect of the strategies on the competitiveness of Vojvodina/Hungary as a rural tourism destination. Authors concluded that a large number of tourist resources and attractions are irreplaceable, and the purpose of formulating and implementing strategies must be to ensure that the use of resource ensure their long-term sustainability. Such a development strategies are processes or activities that correspond to the tourist attractions and resources of destinations, and on the other hand, are aligned with the external environment. Destination competitiveness can be increased by using a strategy of constant innovation and continuous change. In order to be competitive, destination should offer flexible, segmented and customized products. The main methods of developing flexibility for the competitiveness of tourist destinations rely on the organization, management, marketing, distribution and other forms of interactions and relationships between tourism suppliers.
\end{abstract}

Keywords: tourism destination, strategy, competitiveness, management, Vojvodina (Serbia), Hungary

JEL classification: L83, Q13, Z32

\section{Introduction}

In the tourism literature, tourism destination competitiveness is defined as "the ability of the destination to maintain its position on the market and/or to improve it over time" (d'Hartserre, 2000, pp. 239) and "to deliver products and services that are better than on the other destinations, particularly regarding to those aspects of tourism experiences that are important to tourists "(Dwyer et al., 2003, pp. 374).

In the tourism industry, the competition between tourist destinations and products has become very intense which has contributed to greater market transparency, price and other elements of products and services (Cracolici et al., 2008). Global competition in the tourism industry has become a challenge for many countries that are competing to become a desirable tourist destination, so understanding the 
factors that contribute to the competitiveness of destinations is essential to maintain the current level of development of tourist destination, its growth and vitality (Ritchie et al., 1993; Hassan , 2000). Therefore, measurement of competitiveness can be considered as a key factor in ensuring the success of tourist destinations.

Rural tourism is one of the priorities in tourism development in many European countries. Rural tourism market is on the rise, while at the same time the future of many rural areas is uncertain, due to changes in agricultural production and the attractiveness of urban areas due to higher living standards. Rural tourism is considered to be one of the appropriate instruments for the revitalization of rural areas and ensuring a sustainable future through job retention or job creation, support for farms, nature conservation, and the preservation of rural crafts as a tourist attraction. Destinations of rural tourism are based on a complex tourist product, which consists of several partial products (accommodation, transport, food, shops, attractions and other) and is offered to visitors (Roberts et al., 2003; Demonja et al., 2010; Sidali, 2011). These individual tourism enterprises are interdependent and connected, and are primarily small and medium-sized enterprises. Problems in rural tourism which contribute to the reduction of competitiveness are reflected in the existence of strong competition instead of cooperation among providers of tourist products and services in rural areas. Given the importance of tourism to rural areas, determining the factors that influence the improvement of the competitive position of the tourism market is of great importance for their further development.

In this paper, the focus is on one of the three components of the competitiveness of rural tourism destination, and that is the strategy of tourist destinations. The aim of this paper is to analyze the strategies of tourist destinations - factors (marketing, employees, policy of planning and destination development, management of service quality and management of environmental protection) and 24 attributes belonging to this determinant affecting the competitiveness of Vojvodina (Serbia) and Hungary as a destination for rural tourism. Theoretical framework of the strategies of tourism destination is described in the next chapter and after that, results and discussion are presented. In the end, conclusions are made, explaining limitations and possibility for future research.

\section{Strategies of tourism destination - theoretical framework}

A large number of tourist resources and attractions are irreplaceable, and the purpose of formulating and implementing strategies is to ensure long-term viability of resources (Buhalis, 2000). Such a development strategy is processes or activities that correspond to the tourist attractions and resources of destinations, and on the other hand, are aligned with the external environment.

From a marketing perspective, the competitiveness of the destination can be increased using a strategy of constant innovation and continuous change. In order to be competitive, destination should offer flexible, segmented and customized tourism products. The main methods of developing flexibility for the competitiveness of tourist destinations rely on the organization, management, marketing, distribution and other forms of interactions and relationships between tourism suppliers. As suggested in the literature, destination competitiveness can be improved by applying appropriate strategies. Previous studies in the tourism literature can be used as a basis for the development of the strategy for tourist destinations. Derived from Crouch-Ritchie and Dwyer-Kim model of destination competitiveness, this paper discusses the factors of the destination strategy through:

1. Marketing - in the development of rural tourism there is a paradox - the more developed the more it changes the nature of its products. If the village is very 
successful in the development of rural tourism, that will attract investors which may have negative effects on the environment. In this case, the role of marketing strategy is to define guidelines for the creation and protection and preservation of the image and the long-term interests. Achievement of the highest level of tourist satisfaction should be the focus of any marketing philosophy and marketing of rural areas do not need to focus on the space, but should be aimed to provide an authentic experience for visitors. Rural tourism destinations need to think about their tourism products from the perspective of "looking", "buying" and "being" (Clarke, 2005).

2. Employees in the tourism sector and rural tourist facilities - since the quality of services that are consumed in the destination by tourists depends on the attitudes, skills and professionalism of tourist workers, the quality of human resources is crucial for the success of individual companies and the economy as a whole. Due to the development of rural tourism, there is a growing need that the public sector, tourism industry and educational institutions offer courses and programs as a sustainable approach to human resource development. Besides, tourism educators and industry sector are encouraged to work as partners in the formation of high-quality personnel who will possess the necessary practical skills and knowledge to be able to meet the specific needs of the industry (tourists). The partnership between the tourism industry and tourism education institutions is an effective means for achieving quality in education.

3. A policy planning and destination development - policy planning is the process of a comprehensive assessment and analysis of the factors that are important for the future development of the destination. This includes not only the establishment of a strategic vision for a specific area that will reflect the goals and aspirations of the community, but also the identification of priority patterns of resource use and development of appropriate styles that will make the area more attractive and more successful as a tourist destination. Policy planning and destination development is taking place at different levels, and each level focuses on the varying degrees of specificity. At these different levels, planning and development can be addressed separately by a particular unit or area, or should be done in such a way that destination planning is an integral part of overall development plans and policies.

4. Quality Management Services - due to increased competition among tourist destinations, providing quality services is increasingly identified as a key factor for the success of any tourism destination. The necessity of establishing quality standards in the provision of services and the production and monitoring of customer satisfaction are identified as areas that can contribute to improving the quality of services. Setting standards in service delivery is known as a powerful means to guarantee "a priori" level of excellence. Quality Management Services is a way of improving the organization goals and relations with consumers. This is in connection with the level of participation and satisfaction of the people in the organization.

5. Environmental management - in the case of rural tourist destinations, natural environment is one of the most precious resources. This requires a balanced use in accordance with the general principles and practices of sustainability and optimal use of non-renewable resources. Maintaining a high level of environmental quality has become an extremely important element of competitiveness of tourist destinations because of the increasing number of tourists, who consider the quality of the environment as one of the key motives for the choice of destination. Author Mihalić (2000) suggested that the destination environmental management should be done with the establishment of codes of conduct in the environment, developing 
self-awareness and practice of environmental protection, certifying and rewarding best practices. Author Hassan (2000) believes that the level of competitiveness of the tourist destinations is higher if destination makes efforts to preserve the environment, arguing also that self-regulatory actions in the industrial sector and a mandatory set of public policies are managerial efforts to minimize environmental impact and improve the quality of the environment.

\section{Methodology}

Tourism experts from Serbia and Hungary were asked to assess the current state of 24 attributes which affect/could affect the competitiveness of rural tourism destinations in Vojvodina/Hungary. Likert scale of five scores was used, where "1" means very bad condition of the attribute, score "2" bad condition, "3" average condition, "4" very well and "5" excellent condition of the attribute. Respondents were not offered to assess the current state of the attribute in relation to the set or a competitive destination (which would tourism experts identify by themselves) because it would not give a true picture of the competitiveness of Vojvodina, because experts would compare rural tourism in Vojvodina with several different destinations.

In this paper, survey research covered all those tourism experts who have the knowledge and/or experience relevant to the subject, and whose area of research and action is related to rural tourism and competitiveness of tourist destinations. In Vojvodina and selected districts in Hungary, interviewed tourism experts are as follows: teaching staff at higher education institutions, employees of the tourist organizations, employees of national and provincial institutions of importance for the development of tourism, tourism managers of travel agencies, owners of tourism enterprises in rural areas (farms, restaurants, ethno-houses, museums, wineries, souvenir shops, event organizers) and others (societies, associations, clusters).

The survey was conducted in two ways - a personal interview (technique of "face to face") and by sending a questionnaire via e-mail. Research in Vojvodina was conducted in the framework of its three regions - Bačka, Banat and Srem, while research in Hungary was conducted in seven counties - Somogy, Baranya, Tolna, Bács-Kiskun, Csongrád, Békés and Jász-Nagykun-Szolnok. These seven districts in Hungary have similar rural tourism offer as Vojvodina.

Selected tourism experts in Vojvodina were interviewed in the period from September to the first half of December 2015, while in Hungary from the second half of December 2015 until the end of January 2016. The response rate in both countries is about $50 \%$.

Statistical analysis of the data collected through the survey will be done in the software statistical program SPSS 17.

\section{Results and discussion}

Respondents from Hungary and Vojvodina assessed the state of the factors within the determinant "Strategy of tourism destinations". At each of the five subscales (factors) there is a statistically significant difference at the level $p<0.01$ (Table 1). Rural areas of Vojvodina achieve lower scores compared to districts in Hungary. 
Table 1

T-test for Dependent Samples - Comparison of Results between Vojvodina and Selected Districts in Hungary

\begin{tabular}{|c|c|c|c|c|c|}
\hline Factor & $\begin{array}{l}\text { Region/ } \\
\text { Country }\end{array}$ & AS & SD & $\mathbf{T}$ & $\begin{array}{c}\text { Relevanc } \\
\text { e }\end{array}$ \\
\hline \multirow[t]{2}{*}{ Marketing } & Vojvodina & 2.9779 & .58514 & \multirow{2}{*}{10.166} & \multirow[t]{2}{*}{.000} \\
\hline & Hungary & 3.6616 & .52452 & & \\
\hline \multirow{2}{*}{$\begin{array}{l}\text { Employees in the tourism sector } \\
\text { and rural tourist facilities }\end{array}$} & Vojvodina & 2.7623 & .62711 & \multirow[t]{2}{*}{-6.562} & \multirow[t]{2}{*}{.000} \\
\hline & Hungary & 3.2920 & .70415 & & \\
\hline \multirow{2}{*}{$\begin{array}{l}\text { A policy planning and } \\
\text { destination development }\end{array}$} & Vojvodina & 2.4540 & .67165 & \multirow[t]{2}{*}{-9.631} & \multirow[t]{2}{*}{.000} \\
\hline & Hungary & 3.3084 & .78898 & & \\
\hline \multirow[t]{2}{*}{ Quality Management Services } & Vojvodina & 2.7960 & .62153 & \multirow[t]{2}{*}{-4.878} & \multirow[t]{2}{*}{.000} \\
\hline & Hungary & 3.1734 & .65625 & & \\
\hline \multirow[t]{2}{*}{ Environmental management } & Vojvodina & 2.5404 & .77949 & \multirow[t]{2}{*}{-9.308} & \multirow[t]{2}{*}{.000} \\
\hline & Hungary & 3.4489 & .83200 & & \\
\hline
\end{tabular}

Source: Authors based on analysis of data from the survey

The differences in condition for determinant "Strategy of tourism destination" between Vojvodina and Hungary are significant for all the factors, which indicates that the action taken so far have not been effective and that serious approach is necessary for each of the attributes in order to increase the quality of the tourism offer of rural tourism of Vojvodina and attract more demand, which would ultimately brought benefits to all interested parties (stakeholders).

Significant differences for the factor "Marketing" are the results of better organization on the Hungarian side, since the activities during tourists' stay are wellorganized and designed, the focus is on the promotion of the tourism offer both by businesses owners, particularly through tourism organizations and organizations for rural and agro-tourism, but also organized distribution of tourism products across several travel agencies. Holders of the tourist policy in Hungary have realized the importance of well-trained personnel for the successful development of rural tourism, and there are there many opportunities for education through seminars, courses, but they introduced mandatory education expressed in number of hours that the owners of tourist facilities in rural areas should pass. Policy planning and destination development has better average grade in Hungary because for the needs of creating tourism policy, planning and development of rural destinations there are available data on the number and capacity of units and the number of tourists and overnight stays in rural areas since 1998.

\section{Conclusion}

Rural tourism and other forms of tourism encompass many business entities (entities that provide accommodation, food, transport ...) and consumption of these services occurs when a visitor comes to a destination, so the visitors' perception of the quality of overall rural tourism experience is a result of the management of all these aspects. The more positive perception of tourism services, the stronger the feeling of quality is. The functional aspect of quality of services is likely to be more influential than the technical aspects, which means that there is a need for highly skilled labor. During 
the development of human resources in rural areas of Vojvodina, special importance should be given to the training of personnel, ranging from manufacturing to management level. From the perspective of supply side, quality management services and human resource development are co-dependent variables in support of excellence in service. In order to be competitive on the tourism market (rural tourism market), destination marketing is crucial and should be focused on new products and market development. Presented study is just one step in the analysis of the competitiveness of Vojvodina as a destination for rural tourism. The paper points out the weaknesses in the rural tourism of Vojvodina. There is a need to investigate the relative importance of the different dimensions of competitiveness. For example, how important natural resources are in relation to, for example, the hospitality of the local community, or how important the quality of service is in relation to price. Such research should be prepared for certain destinations within Vojvodina (Serbia) and individual segments of tourists. More research should be undertaken on the importance of various attributes of destination competitiveness.

\section{Reference}

1. Cracolici, M.F., Nijkamp, P., Rietveld, P. (2008),"Assessment of tourism competitiveness by analysing destination efficiency", Tourism economics, Vol. 14, No. 2, pp. 325-342.

2. d' Hauteserre, A. M. (2000), "Lessons in managed destination competitiveness: the case of Foxwoods casino resort", Tourism Management, Vol. 21, pp. 23-32.

3. Demonja, D., Ružič, P. (2010). "Ruralni turizam u Hrvatskoj s hrvatskim primjerima dobre prakse i europskim iskustvima (Rural tourism in Croatia with Croatian examples of good practice and European experience)", Samobor, Meridijani.

4. Dwyer, L., Kim, C. (2003), "Destination competitiveness: determinants and indicators", Current Issues in Tourism, Vol. 6, No. 5, pp. 369-414.

5. Hassan, S. S. (2000), "Determinants of Market Competitiveness in an Environmentally Sustainable Tourism Industry", Journal of Travel Research, Vol. 38, No. 3, pp.239-245.

6. Ritchie, J. R. B., Crouch, G. I. (1993), "Competitiveness in International Tourism: A Framework for Understanding and Analysis". In Proceedings of the 43 Congress of the Association Internationale d'Experts Scientifique due Tourisme on Competitiveness of Long-Haul Tourist Destinations, San Carlos de Bariloche, Argentina, pp. 23-71.

7. Roberts, L., Hall, D., Mitchell, M. (2003). "Rural Tourism and Recreation", Principles to practice, London, Ashgate.

8. Sidali, K.L. (2011), "A sideways look at farm tourism in Germany and in Italy", in Sidali, K.L., Spiller, A. and Schulze, B. (Eds.), Food, Agri-Culture and Tourism: Linking Local Gastronomy and Rural Tourism-Interdisciplinary Perspectives, Berlin, Springer, pp. 2-24.

\section{About the authors}

Dunja Demirović is a PhD student of Geosciences, module Tourism, at the University of Novi Sad, Faculty of Sciences, Department of Geography, Tourism and Hotel Management, Serbia. Her research interests include youth behavior in tourism industry, event management and rural tourism. The topic of her dissertation is "Competitiveness of Vojvodina as a rural tourism destination". The author can be contacted at demirovic.dunja2@gmail.com.

Dr Radovan Pejanović is a full professor at the University of Novi Sad, Faculty of Agriculture. He published over 500 bibliographic references in the forms of textbooks, monographs, scientific papers, reviews etc. He is a member of the Scientific Society of Economists of Serbia and president of the Balkan Scientific Association of Agricultural Economists. He is the Chief Editor of "Agronomical Economics" and in the 
Editorial board of "Central European Journal of Applied Life Sciences" journals. He is an associate and coordinator in several national and international (TEMPUS) projects, as well as engaged in scientific research and consultancy services in the field of economics, finance, management and entrepreneurship. The author can be contacted at pejanovic@uns.ac.rs.

Dr Otilija Sedlak is a full professor (Ph.D) of Financial mathematics and Quantitative methods in economy and management at the Faculty of Economics Subotica, University of Novi Sad, Serbia. Professor Sedlak has taken part in numerous scientific and research projects in the field of business administration and financial management among which should be pointed up project: "CoNfIDEKT - Cross-border Network for Innovative Development of Economies and Knowledge Transfer" - for a period 2010/2011; " QURE Increasing Quality of Services and Production in Cross-border Region" - for a period 2012/2014, both IPA Cross-border Co-operation Programme, as financial manager. Author can be contacted at otilijas@ef.uns.ac.rs.

Dr Kristina Košić is an associate professor at the University of Novi Sad, Faculty of Sciences, Department of Geography, Tourism and Hotel Management, Serbia. Her field of research is Tourism Geography. Lecturer of subject: Management of tourist destinations, Rural Tourism, Spa tourism. She published great number of scientific papers, monographs, reviews etc. She was staff member in many research projects financed by Serbian Ministry of Science or other Serbian Institution. Also, she was staff member in one international project (IPA). She took a part in seminar "Education in rural tourism", which organized by Ministry of Tourism of Serbia 2007. The author can be contacted at tinicaus@yahoo.com. 